\title{
Crianças, jovens e a cidade: riscos, violências e delinquências em Portugal
}

\author{
Maria João Leote de Carvalho1, Vera Mónica Duarte²
}

Resumo: Tendo por pano de fundo as profundas mudanças demográficas, sociais e econômicas registradas nos últimos anos no tecido (sub)urbano em Portugal, neste artigo promove-se um diálogo dinâmico entre duas investigações qualitativas desenvolvidas pelas autoras com crianças e jovens envolvidos em violência e delinquência na sociedade portuguesa. No entrecruzamento entre os principais resultados de ambas, centra-se o olhar sobre como crianças e jovens representam a sua participação em atos de violência e delinquência em contexto urbano e como sentem a exposição à violência urbana. Ter em consideração o olhar das crianças e dos jovens sobre os problemas sociais que os afetam abre horizontes que remetem para a sua compreensão como atores sociais na construção da realidade e da mudança social nas mais variadas dimensões. Deste modo, as formas como percecionam, representam e se relacionam com desordens e violência nos locais onde residem não podem ser dissociadas dos processos de socialização e modos de vida que aí desenvolvem e sobre os quais também intervêm. Traz-se ainda para discussão a influência da dimensão do gênero nestas problemáticas, salientando as diferentes expressões que estes fenômenos assumem, bem como determinados contornos identificados no processo de aprendizagem social da delinquência.

Palavras-chave: crianças, jovens, violência urbana, delinquência, género

\begin{abstract}
Within the backdrop of the profound demographic, social and economic changes registered in recent years in the (sub)urban territories in Portugal, this article promotes a dynamic dialogue between two qualitative research undertaken by the authors with children and young people involved in violence and delinquency in the Portuguese society. By crossing the results obtained in both, the authors focused on how children and youth represent their participation in acts of violence and delinquency in urban environments context, and how they represent their exposure to urban violence. Taking into consideration the voice of children

\footnotetext{
${ }^{1}$ Email: mjleotec@sapo.pt. Investigadora do CESNOVA - Centro de Estudos de Sociologia, da Universidade Nova de Lisboa. Doutorada em Sociologia (FCSH-UNL). ${ }^{2}$ Email: vduarte@ docentes.ismai.pt. Professora auxiliar no Instituto Superior da Maia (ISMAI) e investigadora no Centro de Investigação em Ciências Sociais, da Universidade do Minho (CICS/UM) e na Unidade de Investigação em Criminologia Ciências do Comportamento, do Instituto Superior da Maia (UICCC/ ISMAI), da qual é diretora. Doutorada em Sociologia (UM).
}

Latitude, Vol. 7, no 2, pp. 133-166, 2013

DOI: https://doi.org/10.28998/2179-5428.20130208 
and youth about the social problems that affect them opens horizons to their understanding as social actors in the construction of social life and social change, at various dimensions. Thus, the ways in which children and youth perceive, represent and relate to violence and delinquency in the places where they live cannot be dissociated from the socialization processes and ways of life they develop there and on which they are also implicated. The gender influence on violence and delinquency is brought up for discussion by the authors, highlighting the different expressions these phenomena assume, as well as other contours identified in the social learning of delinquency by children and youth.

Keywords: children, youth, urban violence, delinquency, gender

\section{Introdução}

A violência e a delinquência, ${ }^{3}$ nas suas mais variadas formas, são componentes estruturais nas dinâmicas sociais de qualquer comunidade. São problemas sociais que dificilmente podem ser abordados com base em modelos de causalidade, assentes em relações lineares potencialmente passíveis de generalização como se de causas únicas e globais se pudesse falar ignorando-se a complexidade da vida social. A violência e a delinquência não são fenômenos exclusivos das sociedades contemporâneas; existiram desde sempre e em todos os grupos sociais, variando apenas a forma como se caracterizam e se têm tornado visíveis ao longo dos tempos. De igual modo, também a preocupação social sobre estas problemáticas não é nova.

No entanto, se é verdade que os fenômenos de violência são parte constitutiva da vida quotidiana, indissociavelmente ligados à quebra de direitos humanos, parece claro que, no decurso das mudanças sociais registradas nos

\footnotetext{
${ }^{3}$ Neste texto, a delinquência é entendida como uma categoria do desvio reportada aos atos desenvolvidos por crianças e jovens que, à luz das leis penais, configurariam a prática de crime pela quebra ou violação do estabelecido nos normativos jurídicos mas que, pela idade, encontram-se numa situação de inimputabilidade criminal, beneficiando de legislação específica em detrimento da aplicação de um código penal. Em Portugal, sob o ponto de vista jurídico, só a partir dos 16 anos de idade se considera que uma pessoa reúne condições para responder no sistema penal pelos seus atos. Qualquer infração cometida abaixo deste limite etário de imputabilidade criminal, apenas pode conduzir ao estabelecimento de medidas de proteção ou educativas, nunca podendo a criança ou jovem ser submetido a julgamento criminal que leve à execução de uma pena de prisão. Esta orientação decorre do facto de se entender que, até essa idade, não se coloca a necessidade de imposição de um código na execução de uma pena, mas antes uma medida tutelar que possibilite a (re)educação e promova a não reincidência pelo reforço à conformidade social.
} 
últimos anos nas sociedades ocidentais, este problema social surja como um dos principais elementos no campo da análise sociológica quando nela se encontram envolvidos como testemunhas, vítimas ou agressores, os seus membros mais novos: as crianças e os jovens.

Em Portugal, estas questões vêm a ocupar um lugar central de discussão entre a opinião pública, emergindo como preocupação social de primeiro plano, num contexto marcado por incertezas, paradoxos e intensas transformações sociais decorrentes da grave crise socioeconômica e financeira que o país atravessa. Isto é visível em discursos de natureza diversa que apontam para a existência de um vasto leque de percepções, práticas e atitudes perante a violência e a delinquência de crianças e jovens, tendo por pano de fundo um quadro marcado por um crescente reforço das desigualdades sociais. A vivência diária está impregnada de representações sobre este problema social que a todos afeta, surgindo como fonte de informação constante na comunicação social, de acordo com linhas de orientação diferenciadas e sob as mais variadas formas, independentemente do grau efetivo de conhecimento científico que se possua a seu respeito.

Às profundas mudanças demográficas e sociais ocorridas nas últimas décadas associam-se diferentes contornos na natureza e dimensão destes fenômenos se revelam com especial preponderância nas áreas metropolitanas de Lisboa e do Porto. Frequentemente, a sua génese é representada como estando mais associada a modos de vida em determinados núcleos habitacionais das cidades (bairros de construção ilegal, de barracas, ou bairros sociais de realojamento) ${ }^{4}$ do que em outros. Enquanto espaço privilegiado não só da produção, mas também da interação política e social, pelo seu caráter de aglomeração, as cidades e as grandes metrópoles estão plena de contrastes e diferenças que se revelam, a um primeiro olhar, num mosaico humano estruturado em torno de frágeis equilíbrios relacionais e sociais em relação aos quais importa refletir.

O conhecimento da multiplicidade de formas e meios de se viver a violência e delinquência na infância e juventude implica que cada criança e jovem não podem continuar a ser encarada como mero receptor de influências de outros, tendencialmente os mais velhos, numa sociedade em permanente transformação. Primordialmente, crianças e jovens têm de ser olhados como partes ativas na

${ }^{4}$ A opção pelo uso da expressão bairro de realojamento remete para uma medida de política pública de habitação social desenvolvida com forte incidência nas últimas décadas em Portugal, que tem assentado em processos de relocalização de populações desfavorecidas do ponto de visa socioeconómico e habitacional em bairros especificamente construídos para esse fim. Trata-se de uma política que tem conduzido ou pode ter mantido uma concentração de determinados problemas e desvantagens sociais em alguns territórios quando se poderia, eventualmente, ter defendido outras soluções que obstassem a esta concentração. 
construção da sociedade, pela participação num tempo e num espaço em que cada vez mais se veem afastados do controle próximo dos familiares, ponto-chave para a definição de políticas sociais e educativas.

À luz deste enquadramento, e aceitando o repto de estudos recentes que apontam a necessidade de investigações exploratórias que tragam os quadros de vida e as vozes de crianças e jovens para o centro do debate teórico metodológico sobre violência e delinquência, este é um artigo escrito a duas mãos, resultado do cruzamento de reflexões e das conclusões obtidas nas investigações de doutoramento desenvolvidas pelas autoras.

CARVALHO (2010) desenvolveu uma investigação fundada nos campos do interacionismo simbólico, da ecologia social e da sociologia da infância, que teve por principal objetivo analisar os processos de socialização na infância em seis bairros de realojamento na área metropolitana de Lisboa, dando-se especial atenção aos contornos do envolvimento das crianças residentes, de ambos os gêneros, entre os seis e os 12 anos, em atos de violência e delinquência. Entre 2005 e 2009 realizouse um estudo de caso, de base etnográfica, em que se conjugaram diferentes metodologias qualitativas, incluindo técnicas visuais (desenho do bairro e fotografias das comunidades). Numa lógica analítica compreensiva, que teve como ponto de partida a 'voz' das crianças, detectou-se uma precocidade no envolvimento em violência e em práticas de delinquentes que se vê refletida numa diversidade de expressões que tornam visíveis os efeitos de políticas de habitação social assentes na concentração territorial de desvantagens sociais que reforçam as desigualdades sociais e a conflitualidade entre grupos sociais.

DUARTE (2012a) desenvolveu uma pesquisa qualitativa, realizada em 2008 e 2009, que visou estudar as experiências e significados da transgressão nos percursos de vida de jovens em conflito com lei. Assumindo como referente empírico as jovens internadas em Centro Educativo e a executar medidas tutelares educativas não institucionais, sob acompanhamento das Equipas Tutelares Educativas da Direção-Geral de Reinserção Social, ${ }^{5}$ da área da Grande Lisboa, analisaram-se 27 processos individuais e realizaram-se 19 entrevistas. Do cruzamento destas duas técnicas construíram-se retratos sociológicos e das análises de conteúdo e de discurso acedeu-se às densidades biográficas que permitiram explorar os discursos dominantes em relação à transgressão e traçar perfis de percursos transgressivos. A leitura e a discussão dos dados foram feitas nas interfaces do interacionismo simbólico, das teorias da ação estruturada e das perspetivas feministas que, ao situar o debate na perspetiva do sujeito (feminino), não perdessem de vista que as subjetividades são permeadas pelas

5 Atual Direção-Geral de Reinserção e Serviços Prisionais, do Ministério da Justiça, Portugal. 
(im)possibilidades do espelho social que molda performances (de transgressão e de gênero).

É do entrecruzamento entre estes dois estudos sobre violência e delinquência, entre olhares sobre os quadros e os modos de vida na infância e juventude situadas nas margens da sociedade portuguesa, que se constrói este artigo. ${ }^{6}$ Deste modo, com este texto pretende-se centrar o olhar sobre como crianças e jovens representam a sua participação em atos de violência e delinquência em contexto urbano e como sentem a exposição à violência urbana. Trazendo a dimensão do gênero para a discussão, convocam-se alguns dos principais resultados obtidos salientando as diferentes expressões que este fenômeno assume, bem como determinados contornos identificados no processo de aprendizagem social da delinquência.

\section{Viver a cidade, viver a metrópole: dinâmicas urbanas e mudança social}

As sociedades contemporâneas têm vindo a ser palco de profundas transformações sociais e econômicas, fazendo-se as mesmas sentir de forma especialmente intensa no contexto das cidades e das grandes metrópoles (GIDDENS, 1996). Situar os fenômenos urbanos onde crianças e jovens se manifestam implica, em primeiro lugar, atender às diversas dimensões que estão na origem da cidade, conceito ambíguo que é, simultaneamente, "descritivo, que permite detectar uma realidade material concreta, e um conceito interpretativo, na medida em que evoca um conjunto de funções sociais várias que fazem da cidade algo bem diferente de uma empresa ou de uma escola, por exemplo." (RÉMY e VOYÉ, 1994, p. 13). Enquanto espaço privilegiado não só da produção mas também da interação política e social em torno de laços sociais sustentados no fator econômico e nas relações de consumo, pelo seu caráter de aglomeração a cidade está plena de contrastes e diferenças que se revelam, a um primeiro olhar, num mosaico humano estruturado em torno de frágeis equilíbrios relacionais e sociais em relação aos quais importa refletir (GRAFEMEYER, 1994).

O espaço urbano reforça-se como aquele para onde tudo conflui, ou deseja confluir, e disso são exemplo os fluxos migratórios a que se tem vindo a assistir um pouco por todo o mundo. $\mathrm{O}$ aumento populacional vem a ocorrer concomitantemente à sua concentração territorial. Mais de metade da população do planeta vive hoje em cidades e estima-se que, em 2025, a nível mundial, cerca de

${ }^{6}$ De forma a preservar a sua identidade, neste texto os nomes das crianças e jovens foram substituídos por códigos alfanuméricos (CARVALHO, 2010) ou por outros fictícios (DUARTE, 2012a), mantendo-se as opções metodológicas tomadas nas investigações a que dizem respeito. 
$60 \%$ das crianças vivam numa delas (CHRISTENSEN e O'BRIEN, 2003; ONU, 2008). Neste âmbito, reforça-se a ideia da cidade como um produto social (WIRTH, 1956) que constitui "o resultado momentâneo da coexistência de um conjunto de legados das 'cidades' que num mesmo sítio se sucederam e cujas marcas chegaram até nós, e sobre os quais agimos reinventando os lugares e remodelando o sentido da coletividade" (BAPTISTA, 1999, p. 5).

Vivemos numa era de globalização em que a tradicional estratificação dos recursos pelo espaço continua a ser um fato da organização da sociedade (CASTELLS, 1996) e, paradoxalmente, apesar de toda a evolução e progresso, as desigualdades sociais têm vindo a crescer, talvez mesmo, a exacerbar-se (SASSEN, 2001, cit. em SAMPSON, 2002). Se por um lado a globalização tem potenciado uma ideia de desterritorialização da cidade pela difusão de estilos de vida que não estão circunscritos aos seus limites territoriais, por outro, a divisão social do espaço urbano acarreta segregações que se traduzem na desigualdade de oportunidades no acesso a recursos materiais e simbólicos e numa acentuada dificuldade de exercício ao nível da participação social que a todos afeta, em especial as crianças e os jovens.

“Há uma espécie de assimetria brutal entre o modo como cada um de nós sofre os efeitos da cidade e a capacidade de cada um de nós intervir nela. A assimetria é brutal para o comum dos cidadãos. (...) Na cidade, enquanto quadro social em parte institucionalizado, em parte não institucionalizado, verifica-se um contraste bastante acentuado entre a difusão da ideia de cidadania e a carência de mecanismos mais efetivos de participação" (COSTA, 1994, p. 159).

É nas cidades que se fazem sentir com maior incidência estas tensões (HANNERZ, 1980), estando na origem destes processos a acelerada urbanização e a constituição de grandes metrópoles num plano de acentuada desindustrialização sentida a partir do século XIX (VAZ, 2001). A reconfiguração das cidades e das metrópoles para as funções que os novos espaços econômicos, de comunicações e serviços qualificados exigem sustenta a perda de populações do centro para as periferias, num processo de "nova urbanidade descentralizada" (OLIVEIRA et al., 2004, p. 94). A espacialização da diferenciação social tende a revelar-se na emergência de áreas urbanas e suburbanas socialmente desfavorecidas, recorrentemente qualificadas como "críticas", "sensíveis" ou "problemáticas", só para citar três das adjetivações mais usadas neste campo e que dão corpo ao que WACQUANT (2001, cit. em OLIVEIRA et al., 2004, p. 94) designa por uma "política urbana de abandono organizado". A estes contextos, nichos de concentração de 
pobreza e de outros problemas sociais, segregados social e territorialmente, muitas vezes de forma compulsiva sobre aqueles que não dispõem de condições para acesso ao mercado privado de habitação, sobrepõem-se relações de força e de poder entre os diferentes grupos sociais a partir das quais se constroem modos e estilos de vida e metáforas de natureza espacial ('centro', 'margens', 'periferia', 'dentro', 'fora') que são recorrentemente usadas determinando a forma de olhar e agir sobre a divisão social do espaço e as relações entre grupos sociais (VALENTINE, 2001). Num certo paralelismo às comunidades medievais, fortificadas, assiste-se, simultaneamente, a fenômenos de "insulamento voluntário" (OLIVEIRA et al., 2004, p. 95) de outros segmentos da população, numa crescente tendência para a regulação e ordenação do espaço ser feita com base em lógicas de segurança e controle social (TONKISS, 2005).

A cidade é, assim, vista como uma unidade social onde as relações sociais se traduzem na sua morfologia, num determinado modo de territorialidade, isto é, de relação entre o espaço e a vida social (RÉMY e VOYÉ, 1994). O processo de urbanização - entendido como "um processo através do qual a mobilidade espacial vem a estruturar a vida quotidiana" (RÉMY e VOYÉ, 1994, p. 15) - vê-se modificado por essa relação, mas, ao mesmo tempo, também a modifica através das conotações positivas ou negativas que são atribuídas ao seu desenvolvimento, delas resultando um leque de impactos de natureza diversa que se traduzem nas diferentes formas de apropriação e uso do espaço na sociedade.

Neste âmbito, as distâncias espaciais traduzem também as distâncias sociais estabelecidas na interação entre indivíduos (GRAFMEYER, 1994), e mais do que as cidades, são as grandes áreas metropolitanas que constituem o epicentro desta interação. Para alguns autores, (FISHER, 1976), a urbanização tem conduzido ao enfraquecimento dos laços sociais e ao isolamento social, enquanto outros defendem que se trata antes da sua redefinição (LOURENÇO, 2010; SANTOS, 2011). A vida em contexto urbano tem o potencial de proporcionar um maior número de encontros entre indivíduos, mas a maioria destes encontros tende a ser transitório, instrumental ou casual (TONKISS, 2005) e a impessoalidade e superficialidade nas relações constitui a imagem de marca de muitos deles.

A aglomeração populacional, a par do desenvolvimento tecnológico, leva a que grande parte da vida nas metrópoles seja racionalizada em função de interesses instrumentais, sendo de registrar uma particular forma de solidão que atinge todos aqueles que, vivendo lado a lado, não se conhecem. Anonimato, instrumentalidade e fragmentação nas relações num aparente "mundo de estranhos" (LOFLAND, 1973, cit. em TONKISS, 2005, p. 22) são algumas das principais características da interação em meio urbano na medida em que cidades e metrópoles são vastas, densas e diversas. Deste modo, não será de estranhar que níveis elevados de desconfiança mútua, de descrença nas solidariedades pessoais, instituições e 
sistemas de autoridade se vejam refletidos, muitas vezes, em formas de imobilismo e indiferença que movimentos sociais urbanos tentam combater questionando o papel do próprio Estado (CASTELLS, 1996).

Pobreza, exclusão social, marginalidades, crime, violência e delinquência são temáticas recorrentes nos estudos urbanos. É também inquestionável que, à luz das transformações sociais mencionadas, os discursos sobre as culturas da infância e juventude em meio urbano tenham vindo a crescer, ao longo dos tempos, em torno do medo e da insegurança, o que, segundo alguns autores, sustenta a ideia de que viver a cidade, viver a metrópole é, intrinsecamente, viver o medo (OLIVEIRA et al, 2004; GILL, 2007). Da reflexividade que marca as sociedades ocidentais modernas (BECK et al., 1997) tem resultado a (re)descoberta de riscos sociais que atravessam a infância e juventude, sendo a vida das crianças e jovens afetada por constrangimentos de natureza diversa (CARVALHO, 2013). Pensar o lugar de crianças e jovens no espaço urbano no presente requer a convocação de diversas matrizes teóricas, tal a diversidade de abordagens que tem vindo a ser concretizada neste campo, a maioria centrada na noção de "sociedade de risco" (BECK, 1992), na qual se vê colocada em perigo a própria condição social da infância e da juventude.

\section{Definindo violência urbana}

Se é verdade que, nas sociedades contemporâneas, a violência está no horizonte da vida social (LOURENÇO et al., 1998), não é menos verdade que a preocupação sobre as questões da violência e a ideia de se estar perante um seu agravamento sem precedentes não são, historicamente, fatos novos (LOURENÇO e LISBOA, 1998; SANTOS, 2009). Inscrevem-se, pelo contrário, nos discursos sobre a crise ou crises sociais que atravessam as sociedades em diferentes épocas, particularmente nos períodos de intensas e profundas mudanças. Em sociedades fortemente mediatizadas os sistemas simbólicos adquirem uma função primordial na ordenação das questões sociais e das visões coletivas sobre o mundo constituindo parte fundamental da própria realidade. Ultrapassa-se neste posicionamento o problema de saber se são as violências que objetivamente terão aumentado ou se, antes pelo contrário, o que se verifica nas sociedades modernas é a intensificação e alargamento da sua percepção. Porque um e outro ponto representam duas faces de um mesmo objeto, a análise a desenvolver terá de atender à convergência e ao cruzamento entre ambos, elementos indissociáveis no estudo sobre condições sociais em contextos de modernidade (BECK, 1992).

A violência é um problema social de dimensão universal que atravessa fronteiras de ordem cultural, econômica, étnica, religiosa ou de gênero, acabando por se refletir na qualidade de vida dos indivíduos num determinado contexto 
(LOURENÇO e CARVALHO, 2001). Ainda que não exista uma definição universal de violência (LOURENÇO, 2010; SANTOS et al., 2011), a utilização deste termo tem subjacente a ideia de que o ato que qualifica ou a conduta a que se reporta acarretam como consequência o fato de os mesmos serem alvo de uma reação social de condenação, ou mesmo de sanção, por parte de uma dada comunidade. Enquanto fenômeno social indissociavelmente ligado à quebra de direitos humanos, cujas repercussões se estendem muito para além dos mais diretamente nela envolvidos afetando a qualidade de vida dos membros de uma sociedade, a violência é entendida enquanto uma transgressão aos sistemas de normas e valores que se reportam em cada momento, social e historicamente definido, à integridade da pessoa (LOURENÇO e LISBOA, 1992)

A percepção da existência de riscos e perigos, nomeadamente através de práticas de violência, leva a que as comunidades reajam defensivamente através de mecanismos de controle social. Caso não o façam, reduz-se o seu grau de coesão pondo-se em causa a ordem social. Uma vez perturbada, a ordem social tenderá a refazer-se. A verdade é que a ideia de uma expansão difusa da violência nas sociedades contemporâneas, permanente, intensa, associada a uma crescente conflitualidade social evidencia uma crise do contrato social, marcada por rupturas nos laços sociais (SANTOS, 2009). Os modos de vida na contemporaneidade estruturam-se em torno de um ideal de ordem social que se afasta dos tradicionais e onde a transnacionalização dos problemas sociais e a percepção de risco são determinantes. A individualização nos modos de vida, especialmente em contexto urbano, obriga a questionar a definição de violência urbana (LOURENÇO, 2010; SANTOS et al., 2011).

Estima-se que mais de metade da população do planeta viva hoje em cidades com mais de meio milhão de habitantes sendo nestes espaços que se acumula maior riqueza, mais recursos e equipamentos. Mas, simultaneamente é nestes espaços que mais se evidenciam as desigualdades sociais. A violência é um problema das sociedades atuais, urbanas e globais. Constitui um traço fundamental da análise social das dinâmicas da(s) cidade(s) e da(s) metropóle(s), que se edificam num quadro alargado de mudanças sociais, tendo por pano de fundo um fenômeno de globalização que acarreta a diluição de fronteiras e se traduz em fluxos migratórios de natureza e dimensão diferenciadas e distintas das tradicionais.

Um eixo de análise, de caráter sociológico, centra-se recorrentemente nos atores da violência e na sua relação com a sociedade, enquanto um segundo eixo, numa perspetiva antropológica, foca-se na definição cultural de violência, que pressupõe a existência de uma cultura de rua, sustentada num conjunto de ritos, 
códigos e linguagens e onde a violência constitui um elemento aglutinador (LEPOUTRE, 2001; SANTOS, 2009; LOURENÇO, 2010; GAVÍRIA, 2011).

Apesar de não existir uma definição única de violência urbana, na literatura científica destacam-se alguns traços que, mais recorrentemente, a ela são associados. Por um lado, os jovens são frequentemente retratados como atores principais numa multiplicidade de atos que colocam em causa a coesão social, muitas das vezes percepcionados como gratuitos. Não quer isto dizer que sejam os protagonistas exclusivos destas ações, mas o seu envolvimento é objeto de especial preocupação social. Por outro lado, é fulcral a análise da importância do espaço público, e das relações e dinâmicas sociais aí tornadas visíveis, reflexo de relações de poder entre indivíduos e grupos sociais. A violência urbana é um fenômeno plural, diverso, que encerra múltiplas formas, contextos e protagonistas.

Torna-se, assim evidente, como o conceito de violência abrange:

“Um vasto conjunto de comportamentos e ações que poderão ser considerados desviantes e que se integram no leque de atos que vão das incivilidades ao crime. Estes atos estão fortemente associados à emergência do sentimento de insegurança nas sociedades urbanas contemporâneas e que está na origem da centralidade da questão de segurança no discurso político e social atual" (LOURENÇO, 2010, p. 5)

Neste sentido, acentua-se a dialética entre local e global e releva-se a importância, nesta análise, da consideração dos cinco pilares fundamentais da vida social apontados nos estudos mais recentes da ecologia social: organização, coesão, controle, confiança e partilha (SAMPSON e GROVES, 1989; SAMPSON et al., 1997; ELLIOT et al., 1996 2007; KINGSTON et al., 2009). Diversos estudos recentes confirmam uma linha de orientação já presente em muitas pesquisas originais da Escola de Chicago, ou seja, a existência de uma relação positiva entre a concentração de desvantagens sociais em certos espaços urbanos e as práticas de desordens, violência e crime. $\mathrm{O}$ foco de análise foi deslocado dos laços individuais para o da eficácia social dos grupos, fazendo emergir o conceito de eficácia coletiva. Este conceito refere-se aos mecanismos sociais de construção de confiança e de partilha de expectativas entre residentes de um determinado território relativamente ao controle social, particularmente em espaço público e, de modo mais específico, à educação e ação coletiva a desenvolver junto das crianças residentes (MORENOFF et al., 2001). Como provam os resultados de diferentes investigações (SAMPSON e LAUB, 1994; MOIGNARD, 2008), processos sociais fulcrais como o controle social, se exercido nos espaços públicos com base no envolvimento coletivo dos residentes, associa-se negativamente a violência e crime. Independentemente da 
composição sócio demográfica de um território, onde a eficácia coletiva é mais elevada, o nível de desordens, de violência e de alguns crimes é mais baixo (SAMPSON et al., 1999).

\section{Contornos do processo de urbanização na sociedade portuguesa}

De acordo com os discursos públicos e oficiais sobre (in)segurança, Portugal é um país de baixa criminalidade, mas com um crescente sentimento de insegurança (FERNANDES e RÊGO, 2011). Enquanto os dados oficiais dos Relatórios Anuais de Segurança Interna apontam que a criminalidade participada às polícias, especialmente a mais violenta e grave, tem vindo a diminuir no país, ${ }^{7}$ a esfera mediática continua a acentuar que não para de crescer. Mais do que o eventual aumento dos riscos sociais aquilo a que se poderá estar a assistir nos dias de hoje será antes um potencial aumento da sua representação no quotidiano em função da crescente visibilidade que certos atos adquirem, em parte fruto de uma mediatização permanente (BECK, 1992). A explosão de uma sociedade mediática com acesso massivo, e em simultâneo, à mesma informação em qualquer ponto do mundo, acarreta a divulgação e promoção de estilos de vida superando-se em todos os aspetos os limites da territorialidade.

Quer tenha havido a possibilidade ou não de um agregado familiar escolher a localização do seu alojamento, a zona onde se reside influencia claramente as opções de que as crianças e jovens dispõem (WILSON cit. em McCORD, 2002; SEATON e TAYLOR, 2003). A lógica da cidade onde tudo se faz e tudo se permite (VIENNE, 2008) e a prevalência de determinados padrões de vizinhança e de redes sociais em determinadas comunidades que parecem facilitar o acesso a estruturas de oportunidades ilegais são aspetos que devem ser objeto de uma especial atenção de um ponto de vista da definição de políticas sociais.

[descrição do desenho do bairro] "Este é o meu prédio! As pessoas no meu bairro estão sempre à bulha, sempre a fazer barulho, à luta. Ah, faz falta flores, jardim, não há ali nenhum jardim, só há hortas, hortas... falta sossego, sossego, boa vida, o que faz mais falta é mesmo sossego porque estão sempre à bulha, a fazer barulho, a ir à luta e no outro dia é que foi pior: à noite a mãe [nome] foi levada para a esquadra, veio um carro de polícia e

7 Produzidos anualmente pelo Ministério da Administração Interna, estes relatórios constituem um instrumento de análise sobre a criminalidade participada às autoridades policiais, estando disponíveis em: http://www.portugal.gov.pt/pt/osministerios/ministerioda-administracao-interna/quero-saber-mais/sobre-o$\underline{\text { ministerio/rasi.aspx }}$.

Latitude, Vol. 7, no 2, pp. 133-166, 2013. 
depois ela voltou mas antes ia a lutar no polícia e a mãe do [nome] foi buscar o machado mas depois a minha mãe não deixou ver mais e disse 'logo para casa' e eu fui." [meninaF10, 9 anos, Bairro Rosa] (CARVALHO, 2010, p. 296)

Tal como as famílias influenciam o desenvolvimento dos seus membros através da sua situação social e física, também estas sofrem com as influências do meio onde se (des)integram (McCORD, 2002), sendo certo que uma larga parte terá uma capacidade restrita de seleção do local, sobretudo as mais carenciadas dependentes exclusivamente dos serviços de ação social e da execução de programas de habitação social (SEATON e TAYLOR, 2003).

Parte significativa da discussão em torno da violência na sociedade portuguesa centra-se, recorrentemente, na sua expressão em contexto urbano, enquadrada em torno de um conceito de violência urbana cuja operacionalização nem sempre se concretiza de modo preciso e tem sido mais estudado em associação aos processos de urbanização (MOURA, 2003). Isto justifica-se na medida em que, nas últimas décadas, são três os fenômenos que marcam o ordenamento e gestão do território em Portugal: urbanização, metropolização e litorização.

O conhecimento das novas formas de gestão e ocupação do território português, designadamente das transformações do tecido físico (sub)urbano à luz das opções consubstanciadas em processos de urbanização, é incontornável na reflexão atual sobre a problemática da violência e delinquência de crianças e jovens que aqui se toma como objeto de análise. O crescimento das cidades tem-se efetuado em função de novas formas de espacialização do povoamento dando origem a áreas metropolitanas, assentes numa complexa malha social e de ocupação do território português. À modificação do uso do espaço está associada uma elevada mobilidade geográfica decorrente da expansão das vias de comunicação e da existência de novos territórios, de grandes áreas metropolitanas, diversas, plurais, onde se concentra a população, recursos, centros e atividades econômicos, mas também problemas sociais, econômicos e ambientais (LOURENÇO et al., 1998). No interior destes espaços encontram-se quer uma multiplicidade de atividades econômicas quer uma sobreposição de grupos sociais fortemente heterogêneos e em que a multiculturalidade é apenas um dos aspetos a reter. Este processo de transformação social tem subjacente uma facilidade dos transportes - e em especial a sua individualização - acompanhada de uma dispersão espacial das unidades produtivas que sustenta uma forte mobilidade geográfica das populações (LOURENÇO, 2002).

As desigualdades sociais e os fenômenos de exclusão social intensificam-se e ganham diferentes formas de expressão nestas áreas metropolitanas. O mesmo se passa no campo da segurança pública e da criminalidade registrada pelas forças de 
segurança - cerca de dois terços do total das ocorrências participadas às polícias, a nível nacional, é recolhido nas área metropolitanas de Lisboa e do Porto emergindo uma especial representatividade de algumas das suas formas específicas, como a delinquência juvenil e a criminalidade grupal. Perante este quadro, é o desenvolvimento sustentável destas áreas, nas suas diferentes componentes ambiental, econômica e social, que se vê posto em causa e que, por arrastamento, se reflete no desenvolvimento das restantes regiões e num potencial crescimento de sentimentos de insegurança. ${ }^{8}$

“A cidade enquanto espaço predatório é já bem situável no Portugal oitocentista (...). Quanto ao sentimento de insegurança, é preciso avançar um século para o ver surgir - precisamente a distância que medeia entre a percepção dos novos perigos associados à grande cidade e a sua transformação em complexo de elementos discursivos onipresentes no debate público, por via da esfera mediática, e na prática das ciências, por via da construção de um novo objeto de pesquisa" (FERNANDES E RÊGO,

2011, p. 169).

A modernidade tardia portuguesa, inacabada no entender de alguns autores (VIEGAS e COSTA, 1998), faz-se sentir nestas intensas e aceleradas mudanças que vêm a acontecer num padrão regional de desigual distribuição no país. No processo de urbanização acelerada do litoral português que decorre a par da desertificação do interior, o espaço urbano reforça-se como aquele que, como mencionado anteriormente, tudo conflui, ou deseja confluir, e disso são exemplo os fluxos migratórios internos e externos. À desertificação de parte significativa do território nacional, opõe-se um aumento da densidade populacional em algumas regiões. Nos últimos anos, agravou-se o desequilíbrio entre litoral e interior (INE, 2012).

É nas cidades do litoral português, em especial nas áreas metropolitanas de Lisboa e do Porto, que reside o maior número de crianças e jovens, numa lógica que se estende ao resto da população. $O$ contraste entre os aglomerados populacionais do litoral e do interior é acentuado, com os primeiros a apresentar as mais altas taxas de natalidade e os menores índices de envelhecimento. As

\footnotetext{
${ }^{8}$ Emergem novas figuras de ameaça, onde crianças e jovens assumem protagonismos, como o Gang da CREL, em 2000, os bandos que frequentam a Linha de Sintra (principal via férrea de ligação dos concelhos de Sintra e da Amadora a Lisboa), o "arrastão" em Carcavelos, em 2005, o bando associado ao homicídio de Gisberta, um transexual residente na cidade do Porto, a violência ligada as claques de futebol, os "gunas" (designação que
} 
diferenças de desenvolvimento entre o litoral e o interior do país são uma realidade estando os conselhos com maior poder de compra todos localizados no litoral. ${ }^{9}$

\section{O olhar de crianças e jovens: a naturalização da violência urbana}

nasce do discurso do senso-comum na cidade do Porto. Envolvem-se em atividades ilegais regulares, pertencem a zonas empobrecidas, com escolaridades interrompidas, têm marcas de identificação ligada ao vestuário, corte do cabelo, ostentação de acessório, gestualidade específica. Sem estatuto claro de criminosos, situam-se entre o ameaçador/ desordeiro/ criminal. Sentem a polícia na vizinhança e a prisão ao longe), entre outros (FERNANDES e PINTO, 2008).

${ }^{9}$ Lisboa lidera esta lista de que constam mais 38 concelhos (entre um total de 308 no país) que registam um índice de poder de compra superior à média nacional. No fim, encontramse alguns concelhos do interior Norte e Centro (INE, 2009).

A vivência em ambientes densamente povoados, sobretudo urbanos, a desagregação dos laços sociais e as alterações profundas na natureza e estrutura das redes sociais parecem fazer destacar um cada vez maior desejo de manutenção da ordem e respeito pelas normas da comunidade, constituindo a segurança um dos valores fundamentais na interação social indissociável de noções de liberdade e justiça (LOURENÇO, 2009):

A sustentabilidade de uma sociedade depende das formas como estes três conceitos - segurança, liberdade e justiça - se constroem, deles emergindo representações e formas de atuação que se refletem diretamente nas culturas da infância e da juventude.

“[No meu bairro] precisa mais segurança no prédio porque eles vão para lá fumar, estragam o prédio todo, a rua, são bandidos. Neste bairro o que há a mais são bandidos, bandidos e ladrões, carros roubados e putos assaltantes! Carros roubados a fazerem piões e bandidos a roubarem lojas e pessoas. $\mathrm{O}$ meu bairro tem tudo mas falta segurança, é muitos bandidos!" (meninoM70, 11 anos, Bairro Verde, entrevista) (CARVALHO, 2010, p. 386)

[descrição do desenho do bairro] "Por todo o lado que eu vá tem sempre candeeiros quase todos partidos, sempre candeeiros que não funcionam e outros em cima das casas das pessoas a dar luz a mais. Também há muitos cafés cheios de homens a beber e a fumar e às vezes com brigas e batem e fogem. Às vezes a polícia vem mas também tem de fugir porque vão bater neles e com brigas grandes (meninaF19, 8 anos, Bairro Rosa) (CARVALHO, 2010, p. 295) 
[descrição do desenho do bairro] “Este ali em baixo é um homem a atropelar o menino. Este ali do outro lado é o rapaz que matou o outro ao pé da minha casa, foi buscar a pistola e matou-o. No prédio é um homem a dar um tiro na mulher e a mulher a cair da janela e depois ela caiu da janela e os vizinhos mandaram chamar os bombeiros e mais nada. Não gosto mesmo do meu bairro, é muitas desgraças e é mesmo triste, é assim..." (meninaF02, 9 anos, Bairro Branco) (CARVALHO, 2010, p. 163)

Deste modo é de levantar a seguinte interrogação: será que o direito à participação das crianças e jovens na vida social se vê concretizado em todas as suas possíveis dimensões?

As instituições tradicionais de socialização, como a família e a escola, estão no centro de todas as atenções e torna-se necessária a identificação, análise e compreensão do que mudou no seu seio. A família mantém-se como o primeiro agente de socialização e de controle informal; em último, o controle social formal assumido pelas instâncias do Estado, que assim vê conferida a imagem de protetor e vigilante da sociedade, vetor fulcral na manutenção da ordem social. No entanto, na abordagem aos processos de socialização constata-se como uns e outros se encontram sujeitos a transformações que os afastam de modelos anteriores de funcionamento revelando-se, também por si mesmos, espaços privilegiados para a ocorrência de violência. Disso é exemplo a crescente visibilidade de casos de violência doméstica ou de violência nas escolas.

Acompanhando o desenvolvimento do território, os modos de vida de crianças e jovens têm vindo a sofrer amplas transformações, e um dos mais importantes pontos nesta análise tem a ver com o uso do espaço, especialmente em meio urbano (VALENTINE, 2001; CHRISTENSEN e O'BRIEN, 2003).

Na determinação do posicionamento dos adultos perante as crianças e jovens evidenciam-se as designadas "geografias securitárias" (BODY-GENDROT, 2001) ou "geografias da insegurança e do medo" (ESTEVES, 1999), em especial uma "topografia urbana do medo" (FERNANDES, 2003). São características das grandes metrópoles multiétnicas e múlti culturais onde riqueza e exclusão social se encontram lado a lado (LOURENÇO, 2009). Decorrem de processos de forte diferenciação espacial, social e cultural que tanto se associam à criminalidade quanto a outras potenciais situações de risco, nas quais se inclui o aumento populacional ou da densidade do tráfego, e constituem fatores que sustentam a ansiedade parental e familiar em relação à sua própria segurança e dos seus membros mais novos. Na base encontra-se um quadro social complexo onde imagens e representações sobre o risco social, especialmente em zonas urbanas e 
suburbanas, e diferentes concepções sobre infância se constroem em sobreposição (LEE, 2001). Da fragmentação social, tão característica da vida urbana, emerge a tendência para o enfoque territorial de determinados problemas sociais, de certas vulnerabilidades aos riscos sociais que, independentemente da sua proximidade ou desfasamento à realidade, serve para a edificação de modos de identificação a lugares e a práticas e discursos distintos sobre os mesmos. E como refere

BAPTISTA (2003, p. 37) "extensíveis aos diversos meios sociais tais visualizações tornamse mais poderosas quando se conseguem afirmar como verdadeiras."

Esta situação assume contornos bem específicos junto das camadas mais novas da sociedade portuguesa, especialmente entre aqueles que vivem nas periferias das grandes cidades.

“Onde é que fica o Governo? Qual é o bairro onde está o Governo, qual é o bairro?... Quem manda nas escolas? São os Governos?... E se o Governo disser que não é para ficar na escola vamos ter de ir embora e os professores também?..." [meninoM13, 12 anos, Bairro Verde ](CARVALHO, 2010, p. 297). "Qual é o bairro?" é a pergunta desta criança cuja visão do mundo se centra nos limites do território onde reside. Tudo para ele gira em volta do "bairro" que agora é de habitação social mas que anteriormente seria de construção ilegal, de barracas. Mas não só, também o olhar do exterior fecha o "bairro" (seja o atual, seja o anterior) num território específico, estigmatizado, potencialmente perigoso, espaço ameaçador para quem se encontra fora dele. Estes processos de realojamento que visaram, em primeiro lugar, a melhoria das condições de vida de segmentos da população estão na base de áreas residenciais, de dimensão e natureza variada, que de comum têm o fato de abranger residentes que já eram objeto de diversas formas de exclusão social, que partem de uma situação acentuadamente desfavorável do ponto de vista socioeconômico. A elevada concentração de problemas sociais num espaço limitado, apesar de se dispor de uma habitação melhor, constitui o maior desafio que se coloca aos técnicos neste tipo de terreno e cuja resolução requer tempo prolongado. As consequências mais visíveis de algumas destas formas de urbanização são, num primeiro momento, a conflitualidade entre os residentes, entre os residentes e os não residentes e a rápida degradação dessas áreas.

[descrição do desenho do bairro] "Isso aqui é o meu prédio, eu estou aqui em 'puto' a ir abrir a porta do meu prédio a chegar a casa. O que está a mais no meu bairro são aquelas hortas lá em cima, muitos carros nos passeios, aqueles roubados... Sabes aquele café do (...), aquele sítio que não tem 
saída? Era só para a gente brincar e de bicicleta e agora é só carros e corridas. Carros que já atropelaram e vimos a polícia e pusemos logo a sacar. Nada com a polícia, nada! Não quero nada com a polícia!" [meninoM23, 11 anos, $4^{\mathrm{o}}$ ano, Bairro Verde] (CARVALHO, 2010, p. 307)

No estudo de DUARTE (2012a), a maioria das jovens entrevistadas residia em zonas desfavorecidas do ponto de vista econômico e social e partilhava, entre si, as categorias sociais existentes em torno da ideia de bairro, como espaço social problemático, marginalizado e construído em torno de um estereótipo negativo:

"Tinha muito mau ambiente. Tinha muita polícia por causa da droga" [Maria, 18 anos, $\mathrm{MTI}^{9}$;

“É muito problemático, tiroteio, roubo de carros, muita confusão, muitos ciganos e pretos. Era tudo a matar, e 'num sei quê'..." [Joana, 15 anos, MTI]

“... ali tudo trancado em casa, não vejo ninguém na rua, tudo nos seus prédios, nas suas casas... as únicas pessoas que a gente tem na rua são ciganos e pretos... prontos... fico sempre com medo, vou ser assaltada, e prontos! É complicado." [Anabela, 17 anos, $\mathrm{MTIO}^{10}$ ]

“É, a rua em si é calma... o bairro, nem por isso...isso já não é muito calmo. $\mathrm{O}$ que, o que os jovens fazem torna com que a zona, torna-se uma zona um bocado violenta. (...)" [Ivone, 16 anos, MTAE $\left.{ }^{11}\right]$

${ }^{9}$ Medida Tutelar de Internamento em Centro Educativo (medida prevista na Lei Tutelar Educativa - Lei n. ${ }^{\circ}$ 166/99, de 14 de setembro - aplicada a jovens que, entre os 12 e os 16 anos, que tenham cometido um facto qualificado pela lei como crime. É a mais grave das medidas tutelares educativas e "visa proporcionar ao menor, por via do afastamento temporário do seu meio habitual e da utilização de programas e métodos pedagógicos, a interiorização de valores conformes ao direito" (art. $\left.{ }^{0} 17\right)$ ).

${ }^{10}$ Medida Tutelar de Imposição de Obrigações (medida prevista na Lei Tutelar Educativa, está incluída nas medidas não institucionais que tem "por objetivo contribuir para o melhor aproveitamento na escolaridade ou na formação profissional e para o fortalecimento de condições psicobiológicas necessárias ao desenvolvimento da personalidade do menor" (art. $\left.{ }^{\circ} 14\right)$ ).

${ }^{11}$ Medida Tutelar de Acompanhamento Educativo (medida prevista na Lei Tutelar Educativa, está incluída nas medidas não institucionais, e consiste "na execução de um projeto educativo pessoal que abranja as áreas de intervenção fixadas pelo tribunal" (art. ${ }^{\circ}$ 16)). 
Estas percepções surgem, contudo, associadas a sentimentos de pertença e identificação significativos, que Joana [15 anos, MTI] resume desta forma: ... o meu bairro pode cair, mas é o meu bairro, cresci lá. Esta identificação ajuda a explicar os constantes retornos (físicos e simbólicos) ao bairro, mesmo nos casos em que a mudança de residência levou algumas jovens para outros territórios, como nos relata Inês [17 anos, MTAE]:

“Comparado onde eu vivi, é calmo... vivi no Bairro (x). ... quando estava lá, estávamos na rua principal, as pessoas a venderem droga. (...) Lá é mais melhor do que aqui. (...). Mas agora não existe diferença. O que os meus amigos do bairro fazem estes também fazem, a diferença é que antes os daqui eram certinhos e os do bairro não. (...) mas lá sinto-me mais à vontade do que aqui...".

Este processo de identificação não retira, porém, o peso que o "bairro" tem no discurso das jovens. Fátima [16 anos, MTIO] diz: é um bairro, mas gosto... Inês [17 anos, MTAE] põe em destaque esta ideia de que: bairro é bairro... nenhum bairro é certo, não tem pessoas certinhas; Outras, por sua vez, chamam a atenção para os processos de rotulagem e marginalização das pessoas que vivem nos bairros sociais:

"Se vêm parar ao Centros Educativos, ou estiveram em colégios anteriores ou em bairros sociais. [Elisabete, 14 anos, MTI]

“...além disso está mais sujeita a estas situações por ser pobre, por ser negra, por morar em zonas menos boas... mas sim, são boatos...tudo boatos. Isto de que os pretos fazem, os bairros fazem..." [Vera, 16 anos, MTI]

Célia [17 anos, MTIO] conta como utiliza o rótulo do bairro para a prática do crime: eu gosto muito de fazer bluff, numa situação destas têm de acreditar...olha que eu vivo num bairro bué de mau, tens de me dar as coisas, senão eu chamo as pessoas do meu bairro...

O bairro, mais do que local de residência, é um espaço de socialização, de encontros e aprendizagens. O que a umas provoca adrenalina, a outras estimula medos, mas, para todas, o bairro é uma montra de "disponíveis", em que tudo está mesmo à porta [Célia, 17 anos, MTIO]. Esta ideia alimenta uma outra de carácter mais 
reflexivo: se eu continuasse aqui ia continuar com as pessoas com que eu andava, isso iame prejudicar muito... ia ter graves consequências...não sei [Teresa, 16 anos, MTTFC ${ }^{12}$ ].

\section{Espaços de violência e cultura de rua}

Como defende GAVÍRIA (2011, p.59), “da mesma forma que há um tempo de violência, há espaços de violência". Pelo seu caráter de concentração, sob uma mediatização permanente e seletiva, é frequente em determinados bairros de construção ilegal ou bairros sociais de realojamento em Portugal a visibilidade de fenômenos de violência, delinquência ou marginalidade. Embora parte significativa do número desse tipo de atos possa ser inserida no quadro de uma pequena criminalidade de rua e das designadas "incivilidades" (ROCHÉ, 1993), o seu efeito desestruturante das relações sociais é pertinentemente associado à emergência do sentimento de insegurança na maioria das cidades dos países ocidentais. Parte desta violência é desenvolvida por crianças e jovens e é com apreensão que se vem verificando, quase um pouco por toda a Europa, que a diminuição da idade dos seus autores é, tendencialmente, acompanhada de um aumento da violência da agressão, tendencialmente grupal (CARVALHO, 2003, 2004, 2013), muitas vezes associada ao uso de armas.

“Assalto com pistola não é nada!" [rapaz M51, 10 anos, 3ํo ano, Bairro Azul] (CARVALHO, 2010, p.388)

“Ah! Os pequenos é que são bons para roubar! Se tu és pequeno é que é bom para ir roubar, vais e ficas logo a ver como é. É o que é melhor ser pequeno e ir roubar. Chega ali, apanhas uma coisa, outra e ninguém dá do que estás a fazer. Noutros é só ir a correr e já está, roubas tudo. É o que está a dar, mais pequenos roubam 'bués' de coisas aqui, é todos os dias, nem a gente sabe se foi roubada ou não porque é roubar, é só andar na confusão." (meninoM02, 9 anos, Bairro Azul, entrevista) (CARVALHO, 2010, p.389)

Numa sociedade que se terá nuclearizado excessivamente e em que o acesso a determinados bens, mesmo alguns ilegais como as drogas, se banalizou, a radicalização de certos comportamentos assenta numa diversidade de motivos que,

\footnotetext{
${ }^{12}$ Medida Tutelar de Tarefas a Favor da Comunidade (medida prevista na Lei Tutelar Educativa, está incluída nas medidas não institucionais e consiste em o/a menor "exercer atividade em benefício de entidade, pública ou privada, de fim não lucrativo" (art. $\left.{ }^{\circ} 12\right)$ ).
} 
na maior parte das vezes, raramente podem ser analisados de forma singular ou linear, surgindo maioritariamente em acumulação ou articulação.

Nesta linha, no entendimento de BECK (cit. em JAVEAU, 2006), é a própria criança que pode ser vista como um risco, um obstáculo no processo de individualização, uma vez que a sua educação e desenvolvimento implicam custos financeiros e trabalhos específicos e a mesma revela-se um ator social imprevisível, perturbador das relações sociais e dos equilíbrios estabelecidos, sobretudo no seio da família. A concepção das "crianças-rei", pequenos deuses em torno da qual toda a vida familiar e social deve girar (ARIÉS, 1986), parece instalar uma espécie de ditadura de necessidades e direitos cuja efetivação se vê muitas vezes ligada à ideia da infância como fonte de todos os perigos e riscos sociais ligados às formas de violência urbana, familiar e escolar, entre outras (JAVEAU, 2006).

Tendência semelhante acontece relativamente aos jovens. A cultura juvenil hodierna tem-se construído em torno de uma ética de vida que privilegia o lúdico e a imagem e, por esse motivo, tem-se orientado por valores de ordem estética e hedonista, espelho de uma sociedade marcada por um individualismo egoístico (LIPOVETSKI, 1989), onde encontramos indivíduos à procura de sensações euforizantes e predispostos a experimentar novos papéis e a substituir os interditos pela fruição, na procura de uma vida marcada pela "sedução non stop" ${ }^{13}$ Novas liberdades, novas oportunidades que se traduzem, também, em novos horizontes de riscos (BECK, 1992). Estas situações, apesar de não esgotarem a complexidade do problema, vêm mostrar a relevância social, política e científica de refletir sobre alguns novos cenários da violência e delinquência perpetrada por crianças e jovens, mediada por motivações econômicas e de afirmação social, de resolução de conflitos sociais, em que se procura atingir objetivos hedonistas e consumistas e que espelham a reprodução de situações de exclusão e de desqualificação social.

O impacto das dinâmicas territoriais anteriormente mencionado não pode ser ignorado na produção da vida social (GUERRA, 2008; KINTREA et al., 2008), muito em especial nos quadros de vida das crianças e jovens. No âmbito de vários estudos sobre a infância em Portugal, brincar em casa e na escola tende a surgir à cabeça, relegando a rua para um plano secundário, do mesmo modo que o automóvel passou a ser um meio de transporte primordial no campo da mobilidade para um número significativo de crianças residentes no território

${ }^{13}$ Para LIPOVETSKY (1989, pp 17-32) a "sedução non stop" é, no fundo, uma vaga característica do tempo presente que "substitui a coerção pela comunicação, o interdito pela fruição, o anónimo pelo feito por medida, a reificação pela responsabilização, e que, por todo o lado, tende a instituir um clima de proximidade, de ritmo e de solicitude liberta do registo da lei (...). Toda a vida das sociedades contemporâneas é doravante governada por uma nova estratégia que destrona o primado das relações de produção em proveito de uma apoteose das relações de sedução" 
nacional (NETO, 2005; BASTOS et al. 2008). No entanto, para outras, em determinados grupos ou contextos sociais, a rua constitui o principal palco de socialização e não pode ser dissociada da "cultura de rua" que aí se desenvolve (MOIGNARD, 2008; CARVALHO, 2010). Deste modo, emerge um forte contraste entre crianças oriundas de diferentes segmentos da população portuguesa.

Em qualquer ponto do planeta, grande parte da infância e juventude, que não só de bairros sociais, está na rua constituindo esta um lugar fundamental de socialização. Naturalmente, os laços e as ligações à rua são diversos para cada indivíduo, mas a verdade é que a rua é um espaço de socialização primordial nas suas vidas, um espaço inteiro onde se está em função de determinados códigos, de rituais e de linguagens que se conjugam de modo específico e particular com as características de urbanidade do território habitado (LEPOUTRE, 2001). Desta forma, não se pode mais continuar a ignorar o valor da socialização na "escola da rua" (JAMOULLE, 2005) que, em certas vertentes, remete para práticas sociais informais, eventualmente algumas de caráter ilegal, como no tráfico de droga ou no furto de veículos. Estas ações permitem alcançar um estatuto que confere prestígio num contexto social fundamentalmente marcado pela precariedade.

A associação a pares desviantes situa-se, para muitas crianças e jovens, num acumular de riscos, relacionado com o número de contextos com os quais têm ligações negativas. O grupo dá companhia, estímulo e suporte e, neste sentido, as relações de amizade são descritas, pela maioria das jovens entrevistadas por DUARTE (2012), como uma coisa muito importante na sua vida, surgindo como fonte de apoio emocional e social, em grande parte compensador das desestruturações e disfuncionalidades familiares. O grupo de pares torna-se o substituto afetivo de uma família que, no seu entendimento, negou-lhes o apoio de que necessitavam. A densidade dos laços sociais nos grupos faz emergir uma diversidade de manifestações e ações paralelas que tendem a prevalecer sobre a cultura normativa vigente. Tal é o caso do valor das alcunhas, grafitis ou tatuagens, sinais da linguagem de uma cultura de rua; de atitudes, gestos e maneiras de apropriação do mundo; de atividades orientadas para determinados fins precisos; das alianças com 'sócios', com pares marcadas no território; dos interditos religiosos e culturais; das relações de gênero que obrigam a determinadas relações e estatutos sociais (LEPOUTRE, 2001; MOIGNARD, 2008; CARVALHO, 2010).

Paralelamente, a questão de honra, valor fortemente assumido num quadro social desta natureza, constitui frequentemente um elemento catalisador da passagem ao ato violento. Trata-se de uma noção central pela qual crianças, jovens, famílias e grupos se envolvem numa linha de disciplina moral a partir da qual avaliam as suas interações e quais os efeitos perniciosos no caso de assumirem que a sua honra foi atingida por outrem. A percepção de um ato como violento e intencional é, tendencialmente, objeto de uma ação reparadora que pode mesmo 
envolver outra violação de normas e a procura deste tipo de ações é inevitável nas suas vidas neste tipo de contextos. A escola, assim como todos os serviços oficiais ou associados a uma ideia de autoridade ou Estado, podem constituir um alvo privilegiado porque as ofensas e ameaças facilmente evoluem para solidariedades de grupo(s), às vezes até anteriormente opostos. A oralidade é parte fundamental nestes processos de socialização e, muitas vezes, a vítima exterior é encarada como responsável na agressão que sofreu (MOIGNARD, 2008).

Uma das expressões mais difundidas pela prevalência de subculturas de violência passa por uma valorização exacerbada pelo 'banditismo' desde idades muito novas, assentes num certo culto da virilidade que não é exclusivo do sexo masculino.

“-Ah! Eu quero ser ladrão, quero ser ladrão! Conheço mais ou menos muitos ladrões. (...) É bom ser ladrão porque é divertido e mais nada. (...) É andar a brincar com os polícias, ir atrás dos polícias e eles não apanham, às vezes sim mas não apanham mesmo nós. (...) Queria ser um ladrão... um ladrão de roubar carros, roubar um carro só, depois vem a polícia atrás, eu corria e depois fujo e a polícia não encontra. (...) Fujo para casa, é divertido deixar a polícia no poste, eu fujo, a polícia vai e bate no poste e eu fujo para casa, a polícia não vai lá." [meninoM33, 1ํano, Bairro Rosa] (CARVALHO, 2010, p. 327)

Se este menino fica por querer ser "ladrão", já outros dos seus colegas desejam mais ser "bandido" ou até mesmo "chefe dos bandidos". O fascínio que certas crianças, mesmo em idades muito precoces, manifestam sobre o universo simbólico da violência decorre a par de referências identitárias na família e comunidade e da facilidade de experiência destes modos de vida nos seus contextos de residência (CARVALHO, 2010, 2013). Mas não só, a valorização dos jovens que morrem na prática de delitos é também um facto perpetuando-se o reconhecimento de trajetórias desviantes através da criação de mitos e pela difusão de objetos de culto. $^{14}$

\section{A influência do gênero na produção da violência e delinquência}

\footnotetext{
${ }^{14}$ Nomeadamente pela distribuição e venda de camisolas ou de outros objetos com a fotografia dos jovens mortos nessas práticas e/ou em confronto com as autoridades policiais. Por vezes, a venda destes artefactos ajuda a suportar as despesas do próprio funeral para além de constituírem peças fundamentais na elaboração do processo de luto por parte da família e amigos.
} 
Uma das questões frequentemente colocadas para discussão em Portugal prende-se com a influência do gênero na violência e delinquência. Além das diferenças de classe, as questões de gênero têm vindo a ganhar alguma importância na discussão sobre violência e delinquência de crianças e jovens, a vários níveis. Por um lado, como forma de explicar as (in)visibilidades masculinas e femininas na cena da delinquência e das culturas de infância e juventude na sociedade portuguesa; por outro lado, para falar na evolução dos papéis de gênero e da ação exercida pelos mecanismos de controle social, em função desta dimensão de análise.

Tendencialmente retratadas como vítimas, as jovens tornam-se invisíveis como agressoras; e quando surgem associadas a um quadro de delinquência, perpetuam-se representações estereotipadas relacionadas com a ideia de que a jovem delinquente é vítima do seu passado, do seu ambiente e da sua condição feminina, incompatível com o mundo criminal e com a cultura de rua (STEFFENSMEIER e ALLAN, 1996; CHESNEY-LIND, 1997). Além disso, como defendem ROOSMALEN e KRAHN (1996), a razão pela qual a figura feminina não tem aparecido na história da cultura juvenil é porque a cultura feminina tem estado localizada fora da esfera pública e tem sido caracterizada por formas culturais de expressão próprias, que refletem o que McROBBIE e GARBER (1976) designam por secundarização estruturada. Segundo NAYAK e KEHILY (2008, p. 61), os estudos contemporâneos sobre juventude feminina mostram que as feminilidades já não são tão rigidamente definidas ou associada ao espaço doméstico, e que a sua visibilidade é parte de uma "new girl order", que faz entrecruzar dois discursos contraditórios, mas que prevalecem em simultâneo (DUITS, 2008; KEHILY 2008): "girl power" vs. "girls at-risk"..$^{15}$ Se é necessário perceber como as jovens constroem essas feminilidades e questionam o discurso dominante, não se deve desconsiderar, contudo, as formas em que essa autonomia é limitada.

Em Portugal, os estudos em torno das culturas juvenis femininas continuam a ser escassos e constroem-se ignorando as diferentes formas em que as jovens vivem e experienciam as suas vidas. DUARTE-FONSECA (2000) defende que o olhar moralizador, característico dos países da Europa Sul, tem um denominador comum: manter as jovens no espaço privado e dar mais liberdade aos rapazes. Apesar das fortes mudanças sociais registradas no país, nas últimas décadas, este

\footnotetext{
${ }^{15} \mathrm{O}$ primeiro discurso, enquadrado no movimento pós-feminismo, celebra a posição da jovem como sujeito, invocando a importância da assertividade e das expressões individualizadas de poder. O segundo discurso destaca a vulnerabilidade das jovens e os perigos que enfrenta na fase de crescimento, como a gravidez na adolescência, os consumos de drogas ou o envolvimento em práticas criminais e gangues (KELIHY, 2008).
} 
denominador comum parece continuar a refletir-se nas trajetórias de vida dos/as jovens de certos grupos sociais da população portuguesa.

Como demonstrou FONSECA (2001), ${ }^{16}$ as idiossincrasias das culturas juvenis femininas têm a ver com as formas específicas como elas se relacionam e negoceiam espaços de autonomia com a família, com as tarefas domésticas, com o trabalho remunerado, com os pares e a gestão dos tempos livres, e com as experiências na rua e no bairro. Os constrangimentos de gênero e o espaço que as jovens ocupam na sociedade apresentam uma relação estreita com os seus comportamentos, quer sejam normativos (FONSECA, 2001), quer sejam delinquentes, como mostra DUARTE (2012a; 2012b), no seu estudo com jovens em cumprimentos de medidas tutelares educativas, no sistema de justiça tutelar português. A autora dá conta que a violência dos comportamentos das jovens e a liberdade, autonomia e independência que reclamam para si, pelas fugas de casa, pelas experimentações de álcool e drogas, pela prática de ilícitos, entre outros, não deixa de esbarrar na manutenção de discursos e concepções tradicionais de masculinidade e feminilidade:

"para exprimir os seus pontos de vista sobre as responsabilidades familiares e os papéis domésticos (menina... é estar em casa, trabalhar, ser mãe... [Vera, 16 anos, MTI]); para justificar o maior controle que os pais tendem a exercer em suas vidas (cá fora pode engravidar... e por isso reservam mais as filhas dentro de casa [Elisabete, 14 anos, MTI]); "para falar sobre as vivências da maternidade e como esta tem um efeito de "mudança" (ver o mundo com outros olhos [Marta, 18 anos, MTIO]); para se referirem aos projetos de futuro, também estes trespassados pelas marcas de gênero (ter marido, filhos... dois... porque é o que toda gente gosta, acho eu! [Fátima, 16 anos, MTIO]; mas, também, para se exprimirem sobre o papel da menina na transgressão (é rapaz, é normal, eles começam a andar em grupos, nessa vida... mas rapariga...é muito feio [Vera, 16 anos, MTI]). (DUARTE, 2012a, p. 213)

GIODARNO (1978) defende que a aprendizagem da delinquência feminina se faz junto do gênero masculino, situação questionado pelos resultados obtidos por CARVALHO (2010). No seu estudo, esta autora identificou, na quase totalidade dos casos, que este processo ocorreu essencialmente num quadro de matriarquização, sob influência direta de familiares do mesmo gênero: mães, tias,

${ }^{16}$ Estudo qualitativo, desenvolvido em torno das culturas juvenis femininas e dos processos de transição e preparação da escola para o trabalho pago e para as responsabilidades familiares, realizado com sete jovens, dos 15 aos 21 anos, nascidas e criadas numa da zona do centro histórico da cidade do Porto, no Bairro da Sé. 
primas, avós e irmãs. Trata-se de uma orientação que, em alguns casos, se viu depois reproduzir com outras meninas não tendo sido visível uma forte interação direta com o gênero masculino.

“Fomos falar com a mãe de [meninaF35, 9 anos, 3o ano, Bairro Branco] e ela explicou tudo. Ela pôs a roupa, pegou a roupa dela, vestiu a roupa da [loja] e então aí ela disse se queríamos fazer igual a ela. Ela disse para se tirar aquela coisa...aquela... o alarme. A mãe dela ensinou, vais e tiras com os dentes assim... (...) Nós conseguíamos tirar, uma tirava e nós vestíamos. (...) A mãe dela disse e foi ela que a mandou ir porque tem roupa roubada em casa e também tem comprada, mas a maioria roubada e depois ficou com um caso em Tribunal uma vez." [meninaF27, 11 anos, Bairro Rosa, entrevista]

(CARVALHO, 2010, p. 394)

Não se afigura que este processo da participação feminina em delinquência possa ser visto como uma construção de alguma forma de masculinidade, como certos autores argumentam (MILLER, 2002); nas ações e relações sociais estabelecidas identificaram-se indicadores da construção da sua identidade de gênero e as práticas são vistas como "coisas femininas". Mulheres e meninas agem nessa condição não abdicando da sua feminilidade, numa conjugação em que emergiram práticas associadas aos tradicionais papéis femininos e outras mais atípicas, mas que não podem ser dissociadas das mudanças sociais e da evolução do espaço cometido às mulheres nas sociedades contemporâneas. Deste modo, os resultados de GIODARNO (1978) têm de ser questionados à luz das dinâmicas sociais e dos possíveis novos padrões da delinquência feminina. Neste domínio, há crianças e jovens que usam a força e competências que tradicionalmente tendiam a ser vistas exclusivamente como parte do repertório masculino. A sua percepção não é diferenciada em função do gênero, mas antes considerada um recurso perante a 'normalização' da violência a que se encontram sujeitas nos contextos de origem, acabando por constituir um elemento na sua própria defesa e integração no contexto onde vivem (CARVALHO, 2010; DUARTE, 2011; DUARTE, 2012a).

Como defendem CHESNEY-LIND e SHELDEN (1992), as jovens experienciam a sua infância e adolescência pintadas com as cores do gênero.

Também LUCCHINI (1997, pp. 108-111) expõe este argumento quando problematiza o acesso diferencial das jovens à rua. Para o autor, as responsabilidades familiares, normalmente associadas aos trabalhos domésticos e ao cuidado do outro, retêm as jovens em casa. A vigilância familiar exercida sobre elas é muito mais apertada do que sobre as crianças e jovens do gênero masculino, na medida em que o comportamento das jovens tem consequências intra e extra 
familiares, especificamente nas questões relacionadas com a sua reputação na comunidade. Na falta de valorização no interior da família, LUCCHINI (1997) mostra que as jovens, ao contrário dos indivíduos do gênero masculino, não a procuram na rua, por considerarem que é desvalorizante para si próprias. $\mathrm{Na}$ realidade, segundo o autor, as jovens não fazem uma aprendizagem da rua que as prepare para ir para a rua, quando algum fator familiar o despolete. E, nestes casos, elas tendem a procurar, primeiro, uma alternativa no interior da esfera privada parentes, vizinhos, amigos ou companheiros - apoiada pelas representações que têm da rua como um espaço masculino e perigoso e, por isso, menos atrativo.

Tende a ser visível uma certa alternância entre a rua e outros espaços sem ser a rua, como a coabitação temporária com homens mais velhos, passagens intermitentes pela casa de amigos e conhecidos (BELKNAP, 2000; DUARTE, 2012a) ou internamentos em instituições. A este respeito, e segundo DUARTE (2012a), quer as vivências de rua, resultantes dos processos de fuga, quer a intensificação do percurso transgressivo de algumas jovens, tiveram como pano de fundo as amizades "levadas para" e/ou feitas nas instituições de promoção e proteção.

A criação de um novo lar para escapar a situações de violência e ao controle familiar é uma prática tipicamente feminina e as possibilidades da prática da prostituição são mais evidentes nas jovens, o que faz com que se tenda a persistir na associação de determinadas práticas desviantes à figura feminina.

Apesar desse acesso diferencial à rua, não podemos descurar o fato de esta ser também, e cada vez mais, um espaço de sociabilidades e de encontros para ambos os gêneros, um espaço que possibilita visibilidades e onde a experiência é emergente e produtora de narrativas próprias, onde a adrenalina, o perigo e a aventura são parte integrante de seus contos. Não se deve descurar um cenário que parece fazer a triangulação entre família, escola e amigos, que é o espaço do bairro. Segundo FERNANDES (cit. in PEREIRA, 2009, p. 172), "a deriva juvenil é um espaçotempo intersticial, a recriação de uma outra cidade feita de ruas, de percursos, de esquinas (...) para aqueles que vivem o vazio das não-inscrições na escola, no mundo do trabalho, na família".

À imagem do que tem sido apontado pela literatura mais recente (BATCHELOR, 2007, 2009), e ao contrário dos discursos (teóricos) dominantes, o comportamento das jovens, pelos vários percursos de violência, parece ver nascer outras motivações que as colocam no caminho de uma procura mais ativa do risco, da experimentação e da busca de sensações euforizantes, relacionadas com o divertimento e a "adrenalina". Tal dá corpo e forma a uma certa imprevisibilidade que as jovens referem na passagem ao ato, sendo que a ofensa não parece surgir como algo planejado, mas como um meio onde encontram divertimento, onde testam limites, onde expressam emoções e gerem sentimentos e, por este motivo, 
fazem-no maioritariamente em grupo. A atividade delinquente descrita como uma atividade solitária é bastante pontual.

"não foi combinado, nem nada... a gente dizia: vamos àquela! E íamos. Vamos àquele! E íamos. Assaltávamos as pessoas na rua" [Joana, 15 anos, MTI]

"naquela noite nem pensamos em fazer nada daquilo, foi a cena do momento, deu-nos na cabeça e dissemos: vamos lá assaltar aquelas miúdas. Foi assim. A partir daí foram assaltos, agressões" [Elisabete, 14 anos, MTI]

A escolha das vítimas (pessoas) e da abordagem é que parece ser mais seletiva. Escolhem os betos e o bom griffe e, por norma, optam por jovens da mesma idade ou mais novos, da mesma altura e do mesmo sexo. Nem sempre as jovens assumem um papel de protagonistas na prática do ilícito, surgindo em papéis mais secundários e/ou de espectador, mas quando o fazem, mostram como a abordagem segue uma escolha racional de disponibilidades, probabilidades, recursos e riscos.

Esta questão da participação das raparigas na delinquência reaviva a discussão em torno de duas imagens (LUCCHINI, 1997): a da "rapariga-objecto", imagem dominante na literatura e que vê a rapariga como alguém que tem falta de autonomia (...) é caracterizada pelo uso utilitário da sexualidade e pela sua capacidade de manipulação; e a da "jovem-sujeito" que adquire a consciência da sua autonomia em relação aos rapazes, forma bandos compostos por raparigas e decidem quando se associam aos rapazes. Não devemos, contudo, manter esta discussão polarizada, pois corremos o risco de não compreender que os percursos de vida são construídos pelas escolhas e pelas ações que se adoptam dentro de um campo limitado de possibilidades e circunstâncias sociais, familiares, escolares e culturais; de não perceber como é que elas se posicionam face à procura e /ou gestão dos comportamentos de risco e quais as fronteiras da influência/ pressão dos pares, dos namorados, da família; e de não apreendemos a heterogeneidade dos percursos das jovens na delinquência e na transgressão (DUARTE, 2011;

DUARTE, 2012a)

\section{Considerações finais}

Um olhar mais atento sobre os territórios onde as violências e as delinquências de crianças e jovens se produzem traz para discussão contornos sociais e jurídicos que requerem mais reflexão e maior conhecimento. No presente, os novos mosaicos urbanos e a natureza das políticas de habitação na sociedade portuguesa tendem a fazer emergir os resultados de políticas de habitação social na 
produção da violência e delinquência. Tendências registradas na execução destas políticas, designadamente através da construção de bairros sociais de realojamento, têm levado à criação de zonas bem delimitadas no interior das cidades ou nas suas periferias para onde populações se veem deslocadas e artificialmente fixadas. Estes processos de segregação social e urbana estão na base de áreas residenciais, de dimensão e natureza variada, que de comum centram populações objeto de diversas formas de exclusão social. As consequências mais visíveis destas formas de urbanização são a conflitualidade entre os residentes, entre os residentes e os não residentes e a rápida degradação dessas áreas.

Se é certo que esses são espaços onde está identificada a existência de um leque de problemas sociais, designadamente em termos de criminalidade, também é certo que esses problemas não se encontram ou se produzirão apenas no seu interior, assim como não podem ser analisados sem se ter em consideração problemas de funcionamento de sistemas sociais (de ensino, saúde, proteção e ação social, segurança., justiça) quer a montante, quer a jusante (MACHADO e SILVA, 2009; CARVALHO, 2010).

No entender de BODY-GENDROT (1995), muitas das situações de violência em contexto urbano surgem, em grande parte, como consequência das limitações e influências de um espaço mal apropriado porque também ele mal definido onde o desregulamento social, numa ambiguidade quanto aos papéis que cada ator deve assumir, promove o desejo de entrega a atividades desta natureza, seja por afronta consciente à ordem social, seja por mera excitação, prazer ou divertimento em função da ausência de referências estáveis que veiculem quais os limites da atuação individual ou coletiva. Quanto mais heterogênea e desfragmentada uma comunidade for, mais a violência e os atos desviantes e/ou delinquentes, sejam ou não manifestados por crianças, por jovens, individualmente mas sobretudo em grupo(s), tenderão a ser percepcionados como gratuitos (CHAILLOU, 1995).

$\mathrm{O}$ crescimento da indiferença e das des-solidarizações (FERNANDES e PINTO, 2008), que caracterizam os cenários urbanos, têm vindo a danificar a confiança interclassista, fabricadora de medos e distâncias sociais. Vivemos numa era marcada pelos fantasmas da não integração (SOULET, 2000), do medo de "ficar para trás" (BAUMAN, 2007) e de se transformar em pessoa desqualificada (PAUGAM, 2003), atirada para as margens e para as periferias sociais. Fenômenos aos quais crianças e jovens não são indiferentes e que influenciam os processos de interação social no reforço quer da inclusão, quer da marginalização e do desvio.

As não conformidades de crianças e de jovens têm de ser pensadas a partir da sua articulação com as lógicas de exclusão e de segregação em relação com os espaços onde tomam corpo. Não se trata apenas de identificar os atos violentos por si cometidos, mas analisá-los à luz do que são as violências dos espaços físicos e 
sociais sobre eles exercidos. Se a segregação é uma qualidade intrínseca e percepcionada no que diz respeito a determinados territórios, e por arrastamento aos seus residentes, ela reenvia o olhar para as formas e modos como estes vivem na relação com o exterior numa linha, muitas das vezes marcada por sentimentos de dependência, de frustração e, até mesmo, de revolta. Ganha assim corpo o conceito de "delinquência de exclusão" (WACQUANT, 2007) que nasce dos interstícios entre desejos, aspirações e as necessidades básicas, da experiência quotidiana da rejeição e da relegação a que muitos dos residentes em determinados territórios, especialmente urbanos, se vêm sujeitos. Em ambos os estudos que serviram de base a este artigo, parte da violência e delinquência urbana perpetrada pelas crianças e jovens resulta de estratégias de sobrevivência, de procura de visibilidade nas suas comunidades e de participação na vida social (SANTOS et al., 2011).

No fundo, uma forma de violência inerte que acentua um sentimento de fatalidade social que os próprios acabam por interiorizar (MOIGNARD, 2008). E esta cultura de violência centrada na procura de uma dignidade perdida ou esquecida, tende a ser transmitida de geração em geração, relevando a oposição entre "nós" e os "outros" que potencia a resistência à autoridade e reforça as marcas da estigmatização. E como evidenciaram BENBENISTHY e ASTOR (2005) num estudo sobre violência nas escolas, na comparação entre crianças e jovens de diferentes meios, são as oriundas deste tipo de contextos que tendem a apresentar uma maior probabilidade de serem vítimas de atos violentos nos seus contextos porque mais facilmente sujeitas à exploração de redes sociais organizadas em torno do crime.

O exercício da violência e da delinquência, sob as mais diversas formas, que podem oscilar do lúdico ao mais ofensivo são na maioria das vezes parte integrante da cultura da rua onde crianças e jovens vieram a crescer (CARRA, 2001; JAMOULLE, 2005; MOIGNARD, 2008). Esta não tem nada de natural sendo construída socialmente e o uso da violência aparece, assim, normalizado aos olhos daqueles que dela participam e não hesitam em recorrer desde idades bem novas. A prática de delitos surge, essencialmente, associada a uma incapacidade de reconhecer o 'outro' com um estatuto de sujeito, como igual e os delitos têm, sobretudo, uma finalidade: a afirmação de um poder e estatuto social. A visão do mundo vai-se construindo em torno de uma dualidade identitária que oscila entre os "fortes" e os "fracos" e a lei do mais forte, enquanto forma de organização familiar e social legitimada individual e coletivamente em vários contextos, é uma regra presente no desenvolvimento de muitas crianças e jovens em Portugal (CARVALHO, 2003, 2010). Fica evidente como parte significativa das práticas de violência e delinquência de crianças e jovens residentes nestes locais resulta de 
processos estruturais de exclusão social, emergindo o ato violento ou delinquente como norma particular aceite neste contexto (SANTOS et al., 2011.)

Nestas práticas de violência e delinquência e nestes cenários de exclusão social cruzam-se pertenças de género. Meninos e meninas estão cada vez mais presentes nos mesmos espaços e sujeitos às mesmas tensões sociais e (sub) culturais. Cruzamo-nos com diferentes feminilidades onde o risco e a experimentação surgem como eixos estruturantes de muitas das suas ações. Apercebemo-nos da presença das meninas nestas práticas e espaços "tipicamente" masculinos, sem que com isso estejam a construir masculinidades, o que traz à superfície diferentes dimensões e expressões das formas de viver a delinquência no feminino. Mas se é verdade que este aparente novo protagonismo das raparigas chama a atenção para a sua capacidade de agency na delinquência e na violência, não menos verdade é que os seus discursos deixam transparecer como as desigualdades sociais em função do género ainda hoje marcam a condição feminina na sociedade portuguesa.

Mas, acima de tudo, nesta dualidade entre o individual e o social emerge uma ambiguidade estrutural das sociedades que leva a que se torne necessário entender as razões que levam as trajetórias de muitas crianças e jovens a serem atravessadas por problemas sociais de ordem diversa quando, paradoxalmente, nunca como agora se dispôs de tanta informação e de tantos meios para efetivar a melhoria das condições da população (WYNESS et al, 2004).

\section{Referências Bibliográficas}

ARIÈS, Philippe. La infancia. Revista de Educación, 281, 5-17, 1986.

BAPTISTA, Luís Vicente. Cidade e Habitação Social. Oeiras: Celta Editora, 1999.

BAPTISTA, Luís Vicente. Territórios, imagens e poderes. In: CORDEIRO, G.;

BAPTISTA, L. e COSTA, A. (Orgs.). Etnografias Urbanas, Oeiras: Celta Editora, 3542, 2003.

BASTOS, Amélia; FERNANDES, G.; PASSOS, J. MALHO, M. Um Olhar sobre

Pobreza Infantil: análise das Condições de Vida das Crianças, Coimbra: Almedina, 2008.

BATCHELOR, Susan. Getting mad wi' it": risk-seeking by young women'. In:

HANNAH-MOFFAT, K.; O'MALLEY, P (Eds.). Gendered Risks. NY: Routledge, 20522, 2007.

BATCHELOR, Susan. Girls, gangs and violence: assessing the evidencell. Probation Journal, 56 (4), 399-414, 2009.

BAUMAN, ZygmunT. A vida fragmentada: ensaios sobre a moral pós-moderna. Lisboa: Relógio D’Água, 2007. 
BECK, Ulrich; GIDDENS, Anthony e LASH, S (Orgs.). Modernização Reflexiva. São Paulo: UNESP, 1997.

Beck, Urlich. Risk Society: towards a New Modernity. London: Sage Publications, 1992 BENBENISTHY, Rami e ASTOR, Ron. School Violence in Context: Culture, Neighbourhood, Family, School and Gender. New York: University Press, 2005 BODYGENDROT, Sophie. Ville et Violence, Irruption des Nouveaux Acteurs. Paris: Presses Universitaires de France, 1995

BODY-GENDROT, Sophie. Les Villes. La Fin de la Violence?. Paris: Presses de la Fondation Nationale des Sciences Politiques, 2001.

CARRA, Cécile. Délinquance Juvenile et Quartiers «Sensibles». Paris: L'Harmattan, 2001.

CARVALHO, Maria João Leote de. Entre as Malhas do Desvio. Jovens, Espaços, Trajectórias e Delinquências.1.․ volume da Colecção Reinserção Social. Oeiras: Celta Editora, 2003.

CARVALHO, Maria João Leote de. Pelas margens, outras infâncias. Crianças, marginalidades e violências. Infância e Juventude, 4, 51-145, 2004.

CARVALHO, Maria João Leote de. Do Outro Lado da Cidade. Crianças, Socialização e Delinquência em Bairros de Realojamento. Dissertação de Doutoramento em Sociologia, Faculdade de Ciências Sociais e Humanas. Universidade Nova de Lisboa. Disponível em http://run.unl.pt/handle/10362/6132, 2010.

CARVALHO, Maria João Leote de. Childhood, Urban Violence and Territory: Children's Perceptions of Place and Violence in Public Housing Neighborhoods in Portugal", Children, Youth and Environments, 23(1), 2013, Special Issue 'Children, Violence, Youth and the Physical Environment', University of Colorado, 124-154.

Disponível em: http://www.jstor.org/stable/10.7721/chilyoutenvi.23.1.0124, 2013 CASTELLS, Manuel. The Rise of the Network Society. Oxford: Blackwell, 1996.

CHESNEY-LIND, Meda. The female offender, California: Sage Publication, 1997.

CHESNEY-LIND, Meda; SHELDEN, Randall G. Girls delinquency and juvenile justice. California: Brooks/Cole Publishing Company, 1992.

CHRISTENSEN, Pia e O'BRIEN, M. (Orgs.). Children in the City: Home, Neighbourhood and Community, Oxon: Routledge, 2003.

COSTA, António Firmino da; BRITO, Joaquim e FERREIRA, Vítor Matias. Mesaredonda sobre a cidade de Lisboa. Sociologia, Problemas e Práticas, 15, 155-174, 1994. DUARTE, Vera. A presença feminina na delinquência juvenil: olhares e silêncios. In: NEVES, S. (Coord.). Género e Ciências Sociais, Castêlo da Maia: Edições ISMAI,173-195, 2011.

DUARTE, Vera. Discursos e percursos na delinquência juvenil feminina. Famalicão: Editora Húmus, 2012a. 
DUARTE, Vera. Os caminhos de Alice do outro lado do espelho: Discursos e percursos na delinquência juvenil feminina. Perspectivas Online: Humanas $\mathcal{E}$ Sociais
Aplicadas,
(2),
12-16.
Disponível
em: http://seer.perspectivasonline.com.br/index.php/HSA/article/viewFile/224/98 2012b.

DUITS, Linda. Multi-Girl-Culture: An Ethnography of Doing Identity. Amsterdam: Amsterdam University Press, 2008.

ELLIOT, Delbert; WILSON, William; HUIZINGA, David; SAMPSON, Robert; ELLIOT, Amanda e RANKIN, B. The effects of neighborhood disadvantage on adolescent development. Journal of Research in Crime and Delinquency, vol. 33, 4, 389426, 1996.

ESTEVES, Alina. A Criminalidade na Cidade de Lisboa: Uma Geografia da Insegurança, Lisboa: Edições ColibriM 1999.

FERNANDES, Luis. A imagem predatória da cidade. In: CORDEIRO, G.;

BAPTISTA, L.; COSTA, A. (Orgs.). Etnografias Urbanas. Oeiras: Celta Editora, 43-52, 2003.

FERNANDES, Luis e RÊGO, Ximene. Por onde anda o sentimento de insegurança? Problematizações sociais e científicas do medo à cidade, Etnográfica, 15 (1), 167-181, 2011.

FERNANDES, Luis e PINTO, Marta. Juventude urbana pobre e cidade predatória. O guna como figura de ameaça. In: CUNHA, M. (Org.). Aquém e Além da prisão: Cruzamentos e perspectivas. Lisboa: 90. Editora, 177-222, 2008.

FISHER, Claude. The Urban Experience. New York: Harcourt Brace Jovanovich, 1976.

FONSECA, Laura. Culturas Juvenil, percursos Femininos: experiências e subjectividades na Educação de raparigas. Oeiras: Celta Editora, 2001.

GAVÍRIA, Margarita Rosa. Medo ao poder e poder do medo na construção de um território de violência. In: SANTOS, J.V.; TEIXEIRA, A.N e M. RUSSO (Orgs.). Violência e Cidadania. Práticas Sociológicas e Compromissos Sociais, Porto Alegre, UFRGS e Editoa Sulina, 56-76, 2011.

GIDDENS, Anthony. As Consequências da Modernidade, $3^{\text {o }}$ Edição, Oeiras: Celta Editora, 1996.

GILL,Tim. No Fear: Growing Up in a Risk Averse Society, London: Calouste Gulbenkian Foundation, United Kingdom Branch, 2007.

GIORDANO, Peggy, CERNKOVICH, Stephen \& RUDOLPH, Jennifer. Gender, crime and desistance: toward a theory of cognitive transformation. American Journal of Sociology, 107 (4), 990-1064, 2002.

GRAFMEYER, Yves. Sociologie Urbaine. Paris: Éditions Nathan, 1994. 
GUERRA, Isabel. Europa e políticas habitacionais. Mudanças em curso, Cidades Comunidades e Territórios, 17, Lisboa: ISCTE, 2008.

HANNERZ, Ulf. Exploring the City. Inquiries Toward an Urban Anthropology. New York: Columbia University Press, 1980.

INE - INSTITUTO NACIONAL DE ESTATÍSTICA.

INE - INSTITUTO NACIONAL DE ESTATÍSTICA. Censos 2011, XV recenseamento geral da população, $\mathrm{V}$ recenseamento geral da habitação Resultados Provisórios. Lisboa: INE, 2012

JAMOULLE, Pascal. L'école de la rua. La Matière et l'Esprit, 2, 21-38, 2005.

JAVEAU, Claude. La problématisation de l'enfance, des enfants et de l'enfant dans la société dite «du risque». In: SIROTA, Régine (Org.). Éléments pour une Sociologie de l'Enfance, Rennes. Presses Universitaires, 297-306, 2006.

KEHILY, Mary Jane. Taking centre stage? Girlhood and the contradictions of femininity across three generations. Girlhood Studies, 1(2), 51-71. http://oro.open.ac.uk/13139/1/Girlhood Studies.pdf , 2008.

KINGSTON, Beverly; HUIZINGA, David e ELLIOT, Delbert. A Test of Social Disorganization in High-Risk Urban Neighborhoods. Youth and Society, 41, 53-79, 2009

KINTREA, Keith; BANNISTER, Jon; PICKERING, Jon; REID, Maggie e SUZUKI, Naofumi. Young People and Territoriality in British Cities. University of Glasgow: Joseph Rowntree Foundation, 2008.

LEE, Nick. Childhood and Society. Growing Up in an Age of Uncertain. Maidenhead: Open University Press, 2001.

LEPOUTRE, David. Coeur de Banlieue. Codes, Rites et Langages. Paris: Éditions Odile Jacob, 2001.

LIPOVETSKY, Gilles. A era do vazio. Lisboa: Relógio d'Água, 1989.

LOURENÇO, Nelson e CARVALHO, Maria João Leote de. Violência doméstica: conceito e âmbito. Tipos e espaços de violência,. Themis, Ano II, noㄴ, Coimbra, Almedina, 95-121, 2001

LOURENÇO, Nelson. Cidades e sentimento de insegurança: violência urbana ou insegurança urbana? In: JÚNIOR, E. A.; SILVA, J. e J. MARON (Orgs.), Um Toque de Qualidade. Eficiência e Qualidade na Gestão da Defesa Social. Belo Horizonte, Secretaria de Estado da Defesa Social, 1-16, disponível em http://www.fd.unl.pt/Anexos/3841.pdf , 2010.

LOURENÇO, Nelson. Segurança, sentimento de Insegurança e Estado de Direito. O espectro axial da relação de direitos, liberdades e garantias dos poderes do Estado. In: MAI (Org.), Liberdade e Segurança, Ministério da Administração Interna, 8192, 2009. LOURENÇO, Nelson e LISBOA, M. Representações da Violência, Cadernos do CEJ, no2, Lisboa, Ministério da Justiça, Centro de Estudos Judiciários, 1992 
LOURENÇO, Nelson e LISBOA, M. Dez Anos de Crime em Portugal. Análise Longitudinal da Criminalidade Participada às Polícias (1984-1993). Cadernos do CEJ, Lisboa: Ministério da Justiça, Centro de Estudos Judiciários, 1998.

LUCCHINI, Riccardo. A mulher e a desviância ou o debate sobre a especificidade da delinquência femininall. Infância e Juventude, 2, 71-126, 1997.

MACHADO, Fernando Luís e SILVA, Alexandre. Quantos Caminhos há no Mundo? Transições para a Vida Adulta num Bairro Social, Fundação Calouste Gulbenkian, Lisboa: Edições Principia, 2009.

McCORD, Jonh. Forjar criminosos na família, In: Fonseca, A. (Org.). Comportamento Anti-Social e Família. Uma Abordagem Científica. Coimbra: Almedina,15-36, 2002.

McROBBIE, Angela; GARBER, Jenny. Girls and Subculturesll. In: HALL, S. e JEFFERSON, T. (Eds.). Resistance Through Rituals. Youth Subcultures in Post-War Britain. Londres: Hutchinson; Birmingham, 209-222 Disponível em: http://www.gold.ac.uk/media/girls-subculture.pdf, 1976.

MILLER, Jody. The strengths and limits of doing gender' for understanding street $=$ crimell, Theoretical Criminology, 6 (4), 433-460, 2002.

MOIGNARD, Benjamin. L'École et la Rue: Fabriques de Délinquance. Paris: Presses Universitaires de France, 2008.

MORENOFF, Jeffrey; SAMPSON, Robert e RAUDENBUSH, S. Neighborhood inequality, collective efficacy, and the spatial dynamics of urban violence. Criminology, Vol. 39, 3, 517-558, 2001

MOURA, Dulce. Riscos e delinquências juvenis em contextos de realojamento. Cidades - Comunidades e Territórios. CET/ISCTE, 7, 19-36, 2003.

NAYAK, Anoop; KEHILY, Mary. Gender, youth and culture: young masculinities and femininities. NY: Palgrave Macmillan, 2008.

NETO, Carlos (2005). A mobilidade do corpo na infância e desenvolvimento urbano: um paradoxo da sociedade moderna. In: RODRIGUES, D. (Org.). O Corpo que (Des)Conhecemos. Cruz Quebrada: Edições FMH, 15-32, 2005.

OLIVEIRA, Carmen; WOLFF, Maria Palma; CONTE, Marta e HENN, Ronaldo.

Violência e Cidade: existiria uma geografia do crime?, O Público e o Privado, 4, 87101, 2004.

ONU. State of the World's Cities 2008/09. New York: UNHabitat, Disponível em: http://www.unhabitat.org/content.asp, 2008.

PAUGAM, Serge. A desqualificação social: ensaio sobre a nova pobreza. Porto: Porto Editora, 2003.

PEREIRA, Ana Cristina. Meninos de ninguém: o caso Gisberta e outras histórias. Lisboa: Ulisseia, 2009

RÉMY, Jean e VOYÉ, Liliane. A Cidade: Rumo a uma Nova Definição. Porto: Edições Afrontamento, 1994. 
ROCHÉ, Sebastian., Le Sentiment d'Insécurité. Paris: Presses Universitaires de France, (1993)

ROOSMALEN, Erica e Harvey KRAHN. Boundaries of Youth $\|$. Youth and Society, 28 (3). Disponível em: http://yas.sagepub.com/cgi/content/abstract/28/1/3 [acedido em: 7/08/08, 1996.

SAMPSON, Robert J.. Transcending tradition: new directions in community research, Chicago style. Criminology, Volume 40, no2, 213-230, 2002.

SAMPSON, Robert J. e John H. LAUB . Urban poverty and the family context of delinquency: a new look at structure and process in a classic study. Child Development, 65 (special refereed issue on "Children and Poverty"), 523-540, 1994.

SAMPSON, Robert J. e W. B. GROVES. Community structure and crime: testing social- disorganization theory. The American Journal of Sociology, Vol. 94, no4, January, 774-802, 1989.

SAMPSON, Robert J.; RAUDENBUSH, Stephen W. e Felton EARLS. Neighborhoods and violent crime: a multilevel study of collective efficacy. Science, Vol. 277, August, 918-924, 1997

SANTOS, José Vicente Tavares dos; TEIXEIRA, A.N. e M. RUSSO (Orgs.). Violência e Cidadania. Práticas Sociológicas e Compromissos Sociais, Porto Alegre, UFRGS e Editora Sulina, 2011.

SANTOS, José Vicente Tavares dos. Violências e Conflitualidades. Porto Alegre:

Torno Editorial, 2009

SEATON, Eleanor K. e Ronald D. Taylor (2003), Exploring processes in urban, lowincome African American families, Journal of Family Issues, Vol. 24, no 5: 627644 SOULET, Marc-Henry (org.). Da não-integração. Coimbra: Quarteto Editora, 2000. Steffensmeier, Darrel; Allan, Emilie (1996), - Gender and crime: toward a gendered theory of female offending $\|$, Annual Review Sociology, 22, 459-487 TONKISS, Fran. Space, the City and Social Theory, Social Relations and Urban Forms. Malden: Polity Press, 2005.

VALENTINE, Gill. Social Geographies. Space and Society. Essex: Pearson Education Ltd, 2001.

VAZ, Maria João (2001), Introdução. In: PINHEIRO, M.; BAPTISTA, L. e M. J. VAZ (Orgs.). Cidade e Metrópole. Centralidades e Marginalidades. Oeiras: Celta Editora, 2001.

VIEGAS, José Manuel e COSTA, António Firmino (orgs.). Portugal: Que

Modernidade? Oeiras: Celta Editora, 1998.

VIENNE, Philippe. Comprendre les Violences à l'École, Bruxelles, Éditions De Boeck Université, 2008.

WACQUANT, Loïc. Parias Urbains: Ghetto, Banlieues. État. Paris: Éditions La Découverte, 2007. 
Crianças, jovens e a cidade: riscos, violências e delinquências em Portugal

WIRTH, Louis. Community Life and Social Policy. Chicago: University of Chicago Press, 1956.

WYNESS, Michael; HARRINSON, Lisa e Ian BUCHANAN. Childhood, politics and ambiguity: toward an agenda for children's political inclusion. Sociology, Vol. 38, no1, 81-99, 2004. 